\title{
Capital Structure Determinant and Profitability and Their Impact on Firm Value: Study in Indonesian Manufacturing Sector
}

\author{
Evelyn Wijaya ${ }^{1}$, Budiyanto ${ }^{2} \&$ Nur Fadjrih Asyik $^{3}$. \\ ${ }^{1}$ Doctoral Program Student, STIESIA Surabaya, Indonesia \\ ${ }^{2}$ Advisor for a Dissertation, STIESIA Surabaya, Indonesia \\ ${ }^{3}$ Advisor for two Dissertation, STIESIA Surabaya, Indonesia \\ Correspondence: Evelyn Wijaya, STIESIA Doctoral Program Student, Surabaya, Indonesia. E-mail: \\ evelynwijaya53@gmail.com
}

Received: August 2, 2021

doi:10.5539/ijef.v13n10p99
Accepted: August 25, 2021

Online Published: September 5, 2021

\begin{abstract}
Indonesian manufacturing sector becomes an important key for encouraging the national economy. This study aimed to analyze the correlation of capital structure and profitability with firm value by using tangible assets and intangible assets. The population was 145 companies in the manufacturing sector. The sampling technique was purposive sampling that collected a sample of 94 companies during 2010-2019. Data analysis technique was path analysis assisted by SPSS. The result of structural model I stated that firm size, volatility, and uniqueness significantly influenced capital structure, while tangibility insignificantly influenced capital structure. The result of structural model II stated that intellectual capital and capital structure significantly influenced profitability. Further, the result of structural model III stated that capital structure and profitability significantly influenced firm value. The indirect effect test found that profitability could mediate influence between capital structure and firm value.
\end{abstract}

Keywords: tangible asset, intangible asset, capital structure, profitability, firm value

\section{Introduction}

Indonesian manufacturing sector becomes an important key for encouraging the national economy. Indonesian Manufacturing Value Added (MVA) in 2019 reached 4.84\%, while the ASEAN Manufacturing Value Added (MVA) was $4.5 \%$. Globally, Indonesian manufacturing sector was at the $9^{\text {th }}$ rank of all countries in the world (The Global Economy, 2020). Nevertheless, the occurring COVID-19 pandemic has brought a significant impact on the activity of the existing manufacturing sector in Indonesia. This condition is caused by the decline in the domestic demand that, so far, can obtain up to $70 \%$ from the total production of domestic manufacturing industries reflected through the Purchasing Manager Index (PMI) of 47.8 or below 50 in October 2020. The manufacturing sector in Indonesia is still dealing with the declining demand and increased additional costs due to large-scale social restriction (PSBB) that is stricter in both Jakarta and other areas. The price for raw materials including base metal, chemical substances, plastics, and food materials promotes the increase in production costs. This condition certainly forces the businesspersons in the manufacturing sector to decrease the production capacity and hold the investment to keep the company operational survive.

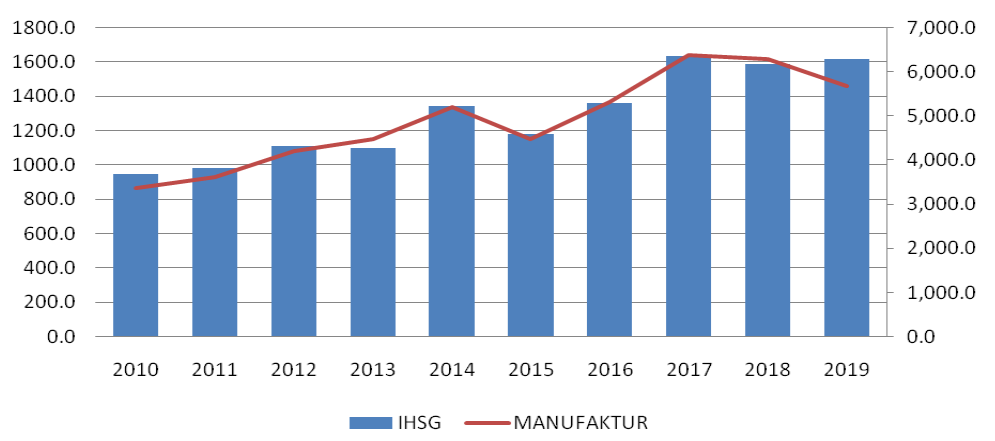

Figure 1. Composite Stock Price Index (IHSG) and manufacturing sectoral index 
Based on Figure 1, it can be seen that IHSG value fluctuates every year. IHSG value in 2010 reached IDR 3,703.5 and IHSG value in 2019 had reached IDR 6,299.6. IHSG ever experienced a significant decline in 2015, however, IHSG proved to pass the condition by the increased stock index in the next period. The condition that happened to IHSG also happened to the manufacturing investment index that it tended to fluctuate. The manufacturing investment index in 2015 declined by IDR 1,151.7 but it increased again and reached IDR $1,460.8$ in 2019. Therefore, it can be said that Indonesian manufacturing sector is one of the mainstays for the national economy.

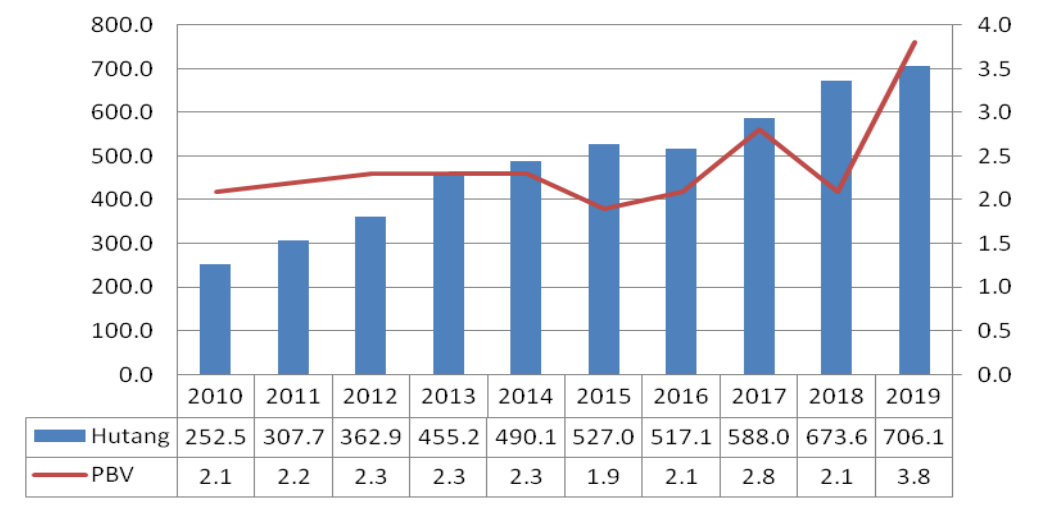

Figure 2. Manufacturing debt and price book value

Based on Figure 2, it can be seen that the increased debt is not always followed by the increased PBV. The PBV value of Indonesian manufacturing sector tended to be stable from 2010 to 2014, however, in 2015, the PBV value decreased, and then, the PBV value tended to fluctuate until 2019. The highest PBV value of Indonesian manufacturing sector was in 2019, showing that the increased company's debt could encourage an increase in firm value. Overall, Figure 2 shows that the performance of Indonesian manufacturing sector is not optimal yet in using debt as an effort to improve firm value.

A study by (Harris \& Raviv, 1991) found that a company with strong financial capacity would obtain easier access to debt for further investment activity. Signaling theory by (Ross, 1977) also stated that the increase in a company's debt supported by achievement for the company's high profit would be a positive signal for the investors. This condition indicates a good company's prospect in the future. This study is supported by a study by (Al Ani \& Al Amri, 2015; Tse \& Rodgers, 2014). In contrast, (Myers \& Majluf, 1984), in Pecking Order Theory, where a company that can produce a profit prefers using funding from the company's internal sources beside using funding from the company's external sources (liability). It can be explains that profitability negatively influences capital structure. This result is supported by a study by (Chandra, 2015; Chen et al., 2014; Fauzi et al., 2013; Ramjee \& Gwatidzo, 2012; Shah \& Kausar, 2012; Thi Hang \& Jay Hung, 2016).

This study aimed to analyze the correlation of capital structure and profitability with firm value by using tangible assets and intangible assets.

\section{Literature Review}

\subsection{Pecking Order Theory}

Pecking Order Theory stated by (Myers \& Majluf, 1984) showed that a company prefers using internal funding to external funding. It explains the reasons that profitable big companies tend to be conservative in using debt for their operational activities. Meanwhile, less-profitable small companies tend to use internal funds first, then applying for a loan to cover the remaining operational funds. Based on this explanation, Pecking Order Theory stated that the market becomes inefficient due to the information gap between company's management and investors.

\subsection{Trade-Off Theory}

Trade-off theory explains that the availability of the factor of bankruptcy risk from the company that will cause additional costs if the company deals with financial distress. Bankruptcy costs will increase along with increased of company's debt. Thus, it can be identified that the higher use of debt, it will increase the financial distress potency and agency cost that will be bigger than the profit of using debt. It indicates that using debt can improve firm value, however, in a certain limit, the increased debt will cause a decline in firm value. 


\subsection{Signaling Theory}

Signaling theory emphasizes the importance of information issued by the company towards the investment decision-making for the company's external parties. The information published as an announcement will provide a signal for investors in investment decision-making. If the announcement has a positive value, the market will react at the time of the announcement is accepted by the market. At the time of information is announced and all actors of the market have received the information, the actors of the market interpret and analyze the information as a good signal or a bad signal at the first time.

\subsection{Resource-Based Theory}

Resources based theory stated that a company has human resources that can stimulate company to have competitive excellence and can lead the company to have a good long-term performance. Precious and rare resources can be led to create competitive excellence so that the resources owned by the company can survive longer and are not easily plagiarized, transferred, or replaced. Each company has unique knowledge, skills, value, and solution that can be transformed into market value (Ulum, 2017). The management of intangible resources helps the company to achieve competitive excellence and increase productivity and market value.

\subsection{Firm Size}

Big companies will have easier access to obtain funding sources from external parties and have a bigger opportunity to win a competition and survive in the industrial market. Big companies have the ability to perform risk diversification so that the bankruptcy risk becomes lower. This condition will make big companies more courageous in decision-making for increasing debt. This statement in line with a study by (Al Ani \& Al Amri, 2015) found that firm size positively influences leverage. This is in line with a study by (Chen et al., 2014; Cheng \& Tzeng, 2011; Lemma \& Negash, 2013; Taghavi et al., 2013; Thi Hang \& Jay Hung, 2016; Yang et al., 2010). However, it is different from a study by (Chandra, 2015; Fauzi et al., 2013; Chandra et al., 2019; Tse \& Rodgers, 2014).

H1: Firm size influenced capital structure in the Indonesia manufacturing sector.

\subsection{Volatility}

Pecking order theory explains that a company with a high risk tends will decrease the use of debt. It is because the higher risk faced by the company will decrease the capacity of a company to pay interests and debt settlement. (Chen et al., 2014) in their study stated that volatility positively and significantly influenced capital structure. This condition describes that the higher debt, the higher risk that will be faced. Meanwhile, a study by (Thi Hang \& Jay Hung, 2016) found that volatility negatively and significantly influenced capital structure. Other studies by (Lemma \& Negash, 2013; Taghavi et al., 2013; Titman \& Wessels, 1988; Chandra et al., 2019; Tse \& Rodgers, 2014; Yang et al., 2010) stated that volatility did not significantly influence capital structure.

$\mathrm{H} 2$ : Volatility influenced capital structure in the Indonesia manufacturing sector.

\subsection{Uniqueness}

A company that produces unique or special products will spend a relatively high cost if the company is liquidated. The consumers will be difficult to find alternative products for relatively unique products. A study related to the correlation between uniqueness and capital structure can be explained through a study by (Titman $\&$ Wessels, 1988) discovering the negative influence between uniqueness and capital structure. The more unique the products manufactured by the company, it will need more unique employees and suppliers. This condition will stimulate the increase in the company's risk and lead investors to consider the application for a loan from the company. This result is not in line with a study by (Chang et al., 2014; Taghavi et al., 2013; Yang et al., 2010).

H3: Uniqueness influenced capital structure in the Indonesia manufacturing sector.

\subsection{Tangibility}

Trade-off theory stated that a company with high tangibility would need more collateral asset that can be used for covering the company's debt when there is a threat of financial distress. Consequently, the company requires more debts to obtain more collateral assets. This statement in line with a study by (Al Ani \& Al Amri, 2015) discovering that tangibility positively and significantly influences leverage. Other relevant studies are those by (Fauzi et al., 2013; Taghavi et al., 2013; Yang et al., 2010). Contrarily, it is different from the studies by (Chandra, 2015; Lemma \& Negash, 2013; Ramjee \& Gwatidzo, 2012; Thi Hang \& Jay Hung, 2016; Titman \& Wessels, 1988).

H4: Tangibility influenced capital structure in the Indonesia manufacturing sector. 


\subsection{Intellectual Capital}

Intellectual capital becomes a new resource for an organization to win a competition. A company that has a good intellectual capital performance tends will have good financial performance. An excellent intellectual capital owned by a company is the organizational resources as a capital for better organizational management. The statement above is in line with the result of a study by (Chen et al., 2005) discovering that intellectual capital positively influences a company's financial performance (ROA). It is in line with the studies by (Kamal et al., 2011; Zehri et al., 2012; Khanqah et al., 2012; Haris et al., 2019). Nevertheless, it is different from the studies by (Firer \& Williams, 2003; Maditinos et al., 2011; Alhassan \& Asare, 2016).

H5: Intellectual capital influenced profitability in the Indonesia manufacturing sector.

\subsection{Capital Structure}

Pecking order theory stated that companies prefer using internal funding to using external funding. It can be inferred that the companies with the ability to produce more profit prefer using funding from the company's internal sources beside using funding from the company's external sources (loan). A study by (Quang \& Xin, 2014) found that capital structure negatively influenced company's profitability. It is in line with the studies by (Akeem et al., 2014; Chadha \& Sharma, 2015; Chen \& Chen, 2011; Salim \& Yadav, 2012). However, it is different from the studies by (Akeem et al., 2014; Gill \& Biger, 2011).

H6: Capital structure influenced profitability in the Indonesia manufacturing sector.

A study by (Khan et al., 2013) found that capital structure positively influenced firm value. The higher company's debt, it will increase company's risk that will motivate the stockholders to demand a higher risk premium. As a result, the stock return expected by the stockholders will increase. It is parallel with studies by (Cheng \& Tzeng, 2011; Ozturk \& Yilmas, 2015; Salim \& Yadav, 2012; Taghavi et al., 2013). Nonetheless, it is different from the studies by (Ahmad et al., 2013; Ghi, 2015; Priya et al., 2015; Abdullah et al., 2015; Salim \& Yadav, 2012; Yang et al., 2010).

H7: Capital structure influenced firm value in the Indonesia manufacturing sector.

\subsection{Profitability}

Myers and Majluf (1984) described a company that could produce high profitability tended to be a fundamental measure for the company's strong finance, so it could motivate the investors to own the company's stock. It will eventually improve the firm value. A study by (Tse \& Rodgers, 2011) found that probability positively and significantly influenced firm value. The higher company's profitability, the higher stock return rate that will be received by the investors. It is in line with the studies by (Ghi, 2015; Khan et al., 2013; Sucuahi \& Cambarihan, 2016).

H8: Profitability influenced firm value in the Indonesia manufacturing sector.

\subsection{Firm Value}

Ross (1977) stated the company that had a high amount of debt would receive more benefits of having a high amount of debt than the sacrifice carried by the company for the debt that is issued. Therefore, increase of debt can encourage an increase in profitability. The increased company's profit provides a positive signal to the capital market that can motivate the investors' interest to investing funds in the company. This causes a high demand for the company's stock in the capital market, and it can stimulate an increase in the stock price. The increased stock price will influence firm value. A study by (Chabachib et al., 2020) stated that profitability did not influence the correlation between capital structure and firm value.

H9: Capital structure influenced firm value through profitability in the Indonesia manufacturing sector. 


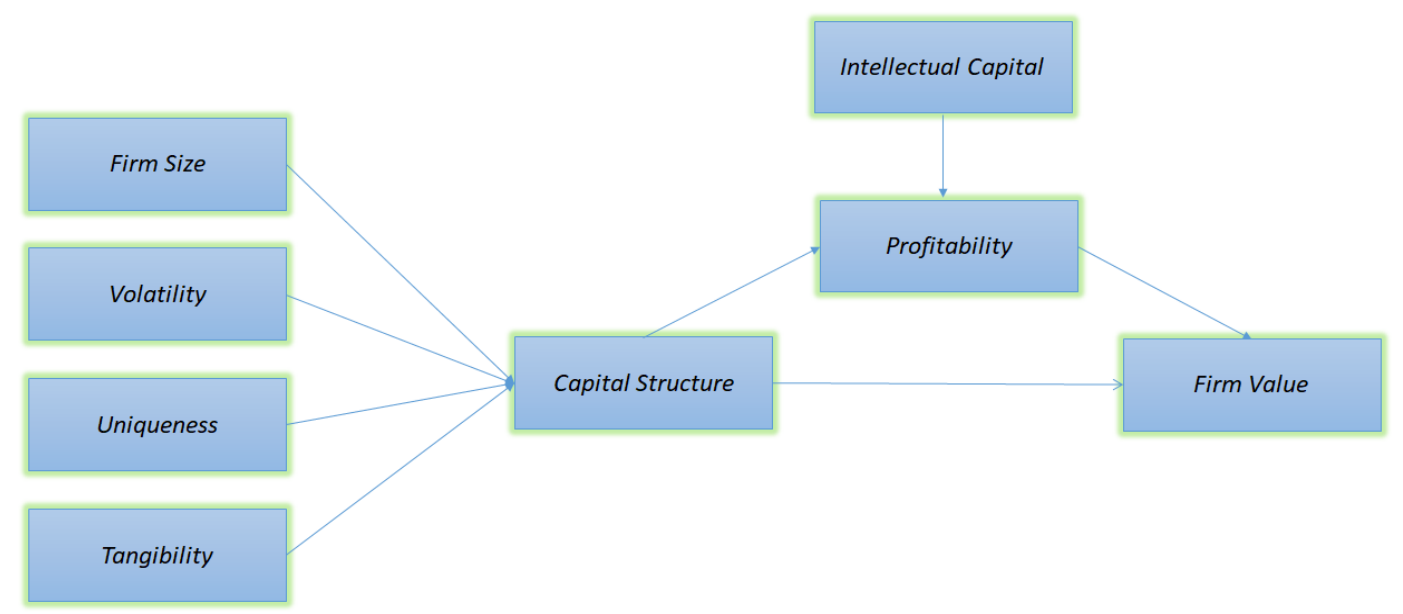

Figure 3. Conceptual framework

\section{Method}

The study population was all companies in Indonesian manufacturing sector that were registered in Indonesia Stock Exchange was 145 companies. To facilitate the data collection, the criteria for data collection was required. Based on the criteria, the total for the study population was 94 companies. Also, the sampling technique was using probability sampling method with the saturated sampling technique.

Table 1. Operational variable

\begin{tabular}{|c|c|c|c|c|}
\hline No & Variable & Indicator & Skala & Source \\
\hline 1 & Firm Size & $=L N($ Total Assets $)$ & Ratio & (Al Ani \& Al Amri, 2015; Quang \& Xin, 2014) \\
\hline 2 & Volatility & $=\frac{\% \text { Change of EBIT }}{\text { Total Assets }} \times 100 \%$ & Ratio & (Yang et al., 2010) \\
\hline 3 & Uniqueness & $=\frac{R \& D}{\text { Total Sales }} \times 100 \%$ & Ratio & (Titman \& Wessels, 1988; Yang et al., 2010) \\
\hline 4 & Tangibility & $=\frac{\text { Fixed Assets }}{\text { Total Assets }} \times 100 \%$ & Ratio & (Quang \& Xin, 2014; Ramjee \& Gwatidzo, 2012) \\
\hline 5 & Intellectual Capital & $=V A C A+V A H U+S T V A$ & Ratio & (Ulum, 2017) \\
\hline 6 & Capital Structure & $=\frac{\text { Total Debt }}{\text { Total Equity }} \times 100 \%$ & Ratio & $\begin{array}{l}\text { (Akeem et al., 2014; Chandra, 2015; Fauzi et al., 2013; Khan et } \\
\text { al., 2013; Mirza \& Javed, 2013; Quang \& Xin, 2014) }\end{array}$ \\
\hline 7 & Profitability & $=\frac{\text { Net Income }}{\text { Total Equity }} \times 100 \%$ & Ratio & (Chadha \& Sharma, 2015; Ghi \& Ba, 2015; Quang \& Xin, 2014) \\
\hline 8 & Firm Value & $=\frac{\text { Stock Price }}{\text { Book Value }} \times 100 \%$ & Ratio & (Ghi \& Ba, 2015; Taghavi et al., 2013; Yang et al., 2010) \\
\hline
\end{tabular}

\subsection{Data Analysis Technique}

Data analysis in this study was done using path analysis. One of the important components in conducting the path analysis was the path diagram.

\section{Result}

\subsection{Normality Test}

Normal distribution was satisfied if the asymp. significant value was more than 0.05 . The following is the result of the normality test for the collected research variables. 
Table 2. Normality test

\begin{tabular}{ccc}
\hline Model & Kolmogorov Smirnov Z & Asymp.Sig \\
\hline Model I & 1.218 & 0.103 \\
Model II & 1.319 & 0.062 \\
Model III & 0.929 & 0.354 \\
\hline
\end{tabular}

Table 2 shows that the asymp. significant value is more than 0.05 . Hence, it can be inferred that the data normality for each study model is categorized as good. Therefore, overall, the data had fulfilled the requirements for the normality test.

\subsection{Outlier Test}

An outlier test was conducted using the casewise diagnostics criteria at a significance level of 0.05 . The result showed that the casewise diagnostics value was at $\mathrm{p}<0.05$. Since the research data had fulfilled the requirements for the normality test, the casewise diagnostics test also did not show any data with the casewise diagnostics value of more than \pm 3 . Therefore, it can be inferred that the research data has no outlier issues.

\subsection{Multicollinearity Test}

The multicollinearity test was conducted by seeing whether the Variance Inflation Factor (VIF) value was less than 10 or not.

Table 3. Multicollinearity test

\begin{tabular}{|c|c|c|c|c|}
\hline Model & Exogen Variable & Endogen Variable & VIF & Tolerance \\
\hline \multirow[t]{4}{*}{ Model I } & Firm Size & Capital Structure & 1.048 & 0.954 \\
\hline & Volatility & Capital Structure & 1.067 & 0.937 \\
\hline & Uniqueness & Capital Structure & 1.006 & 0.994 \\
\hline & Tangibility & Capital Structure & 1.091 & 0.917 \\
\hline \multirow[t]{2}{*}{ Model II } & Intellectual Capital & Profitability & 1.001 & 0.999 \\
\hline & Capital Structure & Profitability & 1.001 & 0.999 \\
\hline \multirow[t]{2}{*}{ Model III } & Capital Structure & Firm Value & 2.399 & 0.417 \\
\hline & Profitability & Firm Value & 2.399 & 0.417 \\
\hline
\end{tabular}

Table 3 shows that the Variance Inflation Factor (VIF) is less than 10 and the tolerance is more than 0.10 . It indicates that the independent data have a multicollinearity issue.

\subsection{Autocorrelation Test}

To know the availability of autocorrelation, the Durbin-Watson test was conducted.

Table 4. Autocorrelation test

\begin{tabular}{ccc}
\hline Model & Durbin Watson & \\
\hline Model I & 2.170 & Negative Autocorrelation \\
Model II & 1.862 & Positive Autocorrelation \\
Model III & 2.020 & No Autocorrelation \\
\hline
\end{tabular}

The result of the type I autocorrelation test obtained a Durbin-Watson value of 2.170. Therefore, it can be inferred that the research data has negative autocorrelation symptoms. The result of the type II autocorrelation test obtained a Durbin-Watson value of 1.862. Hence, it can be inferred that the research data has positive autocorrelation symptoms. The result of the type III autocorrelation test obtained a Durbin-Watson value of 2.020. Accordingly, it can be inferred that the research data has no autocorrelation symptoms.

\subsection{Anova Test}

This test was conducted to obtain an illustration of whether all exogenous variables contained in the research model influenced the endogenous variables. 
Tabel 5. Uji anova

\begin{tabular}{cccc}
\hline & P value & $\alpha$ & \\
\hline Model I & 0.000 & 0.05 & Fit \\
Model II & 0.000 & 0.05 & Fit \\
Model III & 0.000 & 0.05 & Fit \\
\hline
\end{tabular}

Based on the information delivered in Table 5, it is shown that all structural model equations are the best explanatory factor for each change that occurred in the endogenous variables. Thus, this research model was fit to be used for predicting and conducting further analysis.

\subsection{Coefficient of Determination Test}

The type I coefficient of determination test showed a value of $0.571(57.1 \%)$. This explains that $57.1 \%$ of the endogenous variable (capital structure) is influenced by exogenous variables (firm size, volatility, uniqueness, and tangibility), while the remaining or $42.9 \%$ is influenced by other variables outside the study.

The type II coefficient of determination test shows a value of $0.665(66.5 \%)$. This explains that $66.5 \%$ of the endogenous variable (profitability) is influenced by exogenous variables (capital structure and intellectual capital), while the remaining or $33.5 \%$ is influenced by other variables outside the study.

The type III coefficient of determination shows a value of 0.634 (63.4\%). It explains that $63.4 \%$ of the endogenous variable (firm value) is influenced by exogenous variables (capital structure and profitability), while the remaining or $36.6 \%$ is influenced by other variables outside the study.

\subsection{Hypothesis Testing}

Hypothesis testing was intended to know the availability of a significant influence between exogenous variables and endogenous variables.

\subsubsection{Direct Effect Hypothesis}

Table 6. Hypothesis testing

\begin{tabular}{cccc}
\hline Endogen Variable & Exogen Variable & P value & \\
\hline Capital Structure & Firm Size & 0.000 & Accepted \\
Capital Structure & Volatility & 0.000 & Accepted \\
Capital Structure & Uniqueness & 0.011 & Accepted \\
Capital Structure & Tangibility & 0.153 & Rejected \\
\hline Endogen Variable & Exogen Variable & P value & Accepted \\
\hline Profitability & Intellectual Capital & 0.000 & Accepted \\
Profitability & Capital Structure & 0.000 & Accepted \\
Firm Value & Capital Structure & 0.000 & Accepted \\
Firm Value & Profitability & 0.000 & \\
\hline
\end{tabular}

The elaboration for the result of the direct effect hypothesis against the research variable is shown as follows.

1) Firm Size positively and significantly influenced capital structure in the Indonesian manufacturing sector

2) Volatility positively and significantly influenced capital structure in the Indonesian manufacturing sector

3) Uniqueness negatively and significantly influenced capital structure in the Indonesian manufacturing sector

4) Tangibility negatively and insignificantly influenced capital structure in the Indonesian manufacturing sector

5) Intellectual Capital positively and significantly influenced profitability in the Indonesian manufacturing sector

6) Capital Structure negatively and significantly influenced profitability in the Indonesian manufacturing sector

7) Capital Structure positively and significantly influenced firm in the Indonesian manufacturing sector

8) Profitability positively and significantly influenced firm value in the Indonesian manufacturing sector 


\subsubsection{Indirect Effect Hypothesis}

From the result of the study, it was obtained that the direct effect between capital structure and profitability was significant, while the direct effect between profitability and firm value also showed a significant result. In this case, it was obtained that profitability can mediate the influence between capital structure and firm value. Thus, it can be inferred that the findings supported the partially mediated effect.

\section{Discussion}

\subsection{The Influence of Firm Size on the Capital Structure}

Firm size positively and significantly influenced capital structure. It is indicates that firm size directly influences debt value of the companies. Go-public manufacturing companies will need a large amount of capital to sell the stock ownership in the capital market. The companies cannot depend on internal funding only to fulfill the capital needs but the companies need additional external funds that can be fulfilled by loan. This condition describes that the collected result is not relevant to the pecking order theory. This result is in line with the studies by (Chen et al., 2014; Cheng \& Tzeng, 2011; Lemma \& Negash, 2013; Taghavi et al., 2013; Thi Hang \& Jay Hung, 2016; Yang et al., 2010).

\subsection{The Influence of Volatility on Capital Structure}

Volatility positively and significantly influenced capital structure, and it is indicated that the higher company's business risk, it would increase company's debt. The manufacturing companies are the companies focusing on processing industries. With such a manufacturing company's characteristics, the business risk faced by the company is quite high. The variability of revenue obtained by the manufacturing companies fluctuates, so the earnings collected by the companies also tend to fluctuate. Such condition stimulates the manufacturing companies not to reduce the debt, but they keep using the loan to fulfill their operational needs. This condition describes that the collected result is contrary to the trade-off theory. This result is in line with the studies by (Chen et al., 2014; Gwatidzo et al., 2016) but it is different from the studies by (Lemma \& Negash, 2013; Taghavi et al., 2013; Titman \& Wessels, 1988; Chandra et al., 2019; Tse \& Rodgers, 2014; Yang et al., 2010).

\subsection{The Influence of Uniqueness on Capital Structure}

Uniqueness negatively and significantly influenced capital structure. It describes that the more unique the product/policy produced by the company, it will affect the reduction in debt value. The manufacturing company is the processing industry. The activities performed by the company not only include product research and development activity but also include market research and development activity. Thus, the business risk level faced by the company due to this research \& development activity is higher than the company that does not perform research \& development activity. This condition explains that the result collected in this study is relevant to the trade-off theory. The result of this study is in line with the studies by (Titman \& Wessels, 1988), however, it is different from the studies by (Chang et al., 2014; Chandra et al., 2019; Taghavi et al., 2013; Yang et al., 2010).

\subsection{The Influence of Tangibility on Capital Structure}

Tangibility insignificantly influenced capital structure. It shows that the amount of the company fixed asset does not directly affect debt value. A manufacturing company is an industry with a higher amount of fixed assets than that of other companies. Nevertheless, the fixed assets owned by the company are not multifunctional, so it is sufficient to be a warranty for the company's demand for a loan. The creditor will select another payment requirement that can give a higher warranty than the fixed assets, such as stocks, ownership certificates, inventories, accounts receivable, sales and purchase contracts, insurance claims, etc. This condition describes that the result collected in this study is not relevant to the trade-off theory. This result is in line with the studies by (Lemma \& Negash, 2013; Titman \& Wessels, 1988), yet it is different from the studies by (Fauzi et al., 2013; Ramjee \& Gwatidzo, 2012; Thi Hang \& Jay Hung, 2016; Taghavi et al., 2013; Yang et al., 2010).

\subsection{The Influence of Intellectual Capital on Capital Structure}

Intellectual capital positively and significantly influenced profitability, indicating that the better management of intellectual capital, it will directly affect the increase in profitability. In the era of information and knowledge, the key success of a company is not only determined by the tangible asset owned by the company, but it is also determined by the intangible asset to achieve competitive excellence. Through intellectual capital, the company is expected to be able to maximize the resources effectively and efficiently, so it can increase the profitability and the trust levels of investors. This condition explains that the result collected in this study is relevant to the resource-based theory. The result of this study is in line with the studies by (Kamal et al., 2011; Zehri et al., 2012; 
Khanqah et al., 2012; Haris et al., 2019), however, it is different from the studies by (Firer \& Williams, 2003; Maditinos et al., 2011; Alhassan \& Asare, 2016).

\subsection{The Influence of Capital Structure on Profitability}

Capital structure negatively influenced profitability, indicating that the smaller debt, it will increase profitability, and vice versa. The manufacturing sector is one of the sectors providing a big influence on the economy and the sector with a stable business growth compared the other sectors. With such a condition, a company can use the internal funds to finance the operational activity so that it can decrease the company's obligation to pay interests and principal debts; eventually, it can increase the profitability value and the investors' trust. Thus, the manufacturing company can use the retained earnings first to finance the operational activity. This condition describes that the result collected in this study is relevant to the Pecking Order Theory. It is in line with the studies by (Akeem et al., 2014; Chadha \& Sharma, 2015; Chen \& Chen, 2011; Quang \& Xin, 2014; Salim \& Yadav, 2012), yet it is different from the studies by (Al Ani \& Al Amri, 2015; Tse \& Rodgers, 2014).

\subsection{The Influence of Capital Structure on Firm Value}

Capital structure positively and significantly influenced firm value, indicating that the higher of the company's debt, it will affect firm value. The amount of debt will affect the company equity that will lead to an increase in the company's productivity and performance during a certain period. Besides, the company can also perform a business expansion that is believed to be able to increase the company's revenue in the future. Consequently, the stock price and firm value will increase. This condition explains that the result collected in this study is relevant to the trade-off theory. This result is in line with the studies by (Cheng \& Tzeng, 2011; Salim \& Yadav, 2012; Taghavi et al., 2013), however, it is different from the studies by (Ahmad et al., 2013; Ghi, 2015; Priya et al., 2015; Salim \& Yadav, 2012; Abdullah et al., 2015; Yang et al., 2010).

\subsection{The Influence of Profitability on Firm Value}

Profitability positively and significantly influenced firm value, showing that the amount of the company's profitability will directly affect firm value. The higher the company's profitability, the more investors that will seize the positive signal from the company and it will stimulate the increase in firm value. This condition describes that the result collected in this study is relevant to the signaling theory. The result of this study is in line with the studies by (Chandra et al., 2019; Khan et al., 2013; Sucuahi \& Cambarihan, 2016; Yang et al., 2010).

\subsection{The Influence of Capital Structure on Firm Value through Profitability}

The result of the hypothesis testing obtained that profitability could mediate influence between capital structure and firm value in the manufacturing sector. The result of this study is not in line with the studies by (Chabachib et al., 2020). Consequently, the amount of the company's debt will directly affect firm value through the involvement of earnings generated by the company during a certain period.

\section{Conclusion}

Manufacturing companies are the companies focusing on processing activities to fulfill the company's operational needs by not only using internal funds but companies also need additional funds from the companies' external sources. The manufacturing company that can generate a high profit will provide a positive signal to the investors and it can stimulate the increase in firm value. Intellectual capital plays an important role in increasing the company's profitability. Currently, the role of intellectual capital is considered more important by the company to achieve competitive excellence.

\section{References}

Abdullah, M. N., Parvez, K., Karim, T., \& Tooheen, R. B. (2015). The Impact of Financial Leverage and Market Size on Stock Returns on the Dhaka Stock Exchange: Evidence from Selected Stocks in the Manufacturing Sector. International Journal of Economics, Finance and Management Sciences, 3(1), 10-15. https://doi.org/10.11648/j.ijefm.20150301.12

Ahmad, H., Fida, B. A., \& Zakaria, M. (2013). The Co-determinants of Capital Structure and Stock Returns: Evidence from the Karachi Stock Exchange. The Labore Journal of Economics, 18(1), 81-92. https://doi.org/10.35536/lje.2013.v18.i1.a4

Akeem, L. B., Terer, E., Kiyanjui, M. W., \& Kayode, A. M. (2014). Effects of Capital Structure on Firm's Performance: Empirical Study of Manufacturing Companies in Nigeria. Journal of Finance and Investment Analysis, 3(4), 39-57. 
Al Ani, M. K., \&Al Amri, M. S. (2015). The Determinants of Capital Structure: An Empirical Study of Omani Listed Industrial Companies. Verslas: Teorija Ir Praktika, 16(2), 159-167. https://doi.org/10.3846/btp.2015.471

Alhassan, A. L., \& Asare, N. (2016). Intellectual Capital and Bank Productivity in Emerging Market: Evidence from Ghana. Management Decision, 54(3), 589-609. https://doi.org/10.1108/MD-01-2015-0025

Chabachib, M., Hersugondo, H., Ardiana, E., \& Pamungkas, I. D. (2020). Analysis of Company Characteristics of Firm Value: Profitability as Intervening Variables. International Journal of Financial Research, 11(1), 60-70. https://doi.org/10.5430/ijfr.v11n1p60

Chadha, S., \& Sharma, A. K. (2015). Capital Structure and Firm Performance: Empirical Evidence from India. Vision, 19(4), 295-302. https://doi.org/10.1177/0972262915610852

Chandra, T. (2015). The Determinants of the Capital Structure: Empirical Evidence from Indonesian Stock Exchange Companies. Revista Kasmera, 43(2), 76-87.

Chandra, T., Junaedi, A. T., Wijaya, E., Suharti, S., Irman, M., \& Martha, N. (2019). The Effect of Capital Structure on Profitability and Stock Returns Empirical Analysis of Firms Listed in Kompas 100. Journal of Chinese Economic and Foreign Trade Studies, 12(2), 74-8. https://doi.org/10.1108/JCEFTS-11-2018-0042

Chang, C., Chen, X., \& Liao, G. (2014). What are the Reliably Important Determinants of Capital Structure in China? Pacific-Basin Finance Journal, 30, 87-113. https://doi.org/10.1016/j.pacfin.2014.06.001

Chen, J., Jiang, C., \& Lin, Y. (2014). What Determine Firms' Capital Structure in China? Managerial Finance, 40(10), 1024-1039. https://doi.org/10.1108/MF-06-2013-0163

Chen, L. J., \& Chen, S. Y. (2011). The Influence of Profitability on Firm Value with Capital Structure as the Mediator and Firm Size and Industry as Moderators. Investment Management and Financial Innovations, $8(3), 121-129$.

Chen, M., Cheng, S., \& Hwang, Y. (2005). An Empirical Investigation of the Relationship Between Intellectual Capital and Firms' Market Value and Financial Performance.Journal of Intellectual Capital, 6(2), 159-176. https://doi.org/10.1108/14691930510592771

Cheng, M. C., \& Tzeng, Z. C. (2011). The Effect of Leverage on Firm Value and How the Firm Financial Quality Influence on This Effect. World Journal of Management, 3(2), 30-53.

Fauzi, F., Basyith, A., \& Idris, M. (2013). The Determinants of Capital Structure: An Empirical Study of New Zealand-Listed Firms. Asian Journal of Finance \& Accounting, 5(2), 1-21. https://doi.org/10.5296/ajfa.v5i2.3740

Firer, S., \& Williams, S. M. (2003). Intellectual Capital and Traditional Measures of Corporate Performance. Journal of Intellectual Capital, 4(3), 348-360. https://doi.org/10.1108/14691930310487806

Ghi, T. N. (2015). The Impact of Capital Structure and Financial Performance on Stock Returns of the Firms in Hose. International Journal of Information Research and Review, 2(06), 734-737.

Gill, A., Biger, N., \& Mathur, N. (2011). The Effect of Capital Structure on Profitability: Evidence from the United States. International Journal of Management, 28(4), 3-15.

Haris, M., Yao, H. X., Tariq, G., Malik, A., \& Javaid, H. M. (2019). Intellectual Capital Performance and Profitability of Banks: Evidence from Pakistan. Journal of Risk and Financial Management, 12(56), 1-26. https://doi.org/10.3390/jrfm12020056

Harris, M., \& Raviv, A. (1991). The Theory of Capital Structure. The Journal of Finance, 46(1), 297-355. https://doi.org/10.1111/j.1540-6261.1991.tb03753.x

Kamal, M. H. M., Mat, R. C., Rahim, N. A., Husin, N., \& Ismail, I. (2011). Intellectual Capital and Firm Performance of Commercial Banks in Malaysia. Asian Economic and Financial Review, 2(4), 577-590.

Khan, W., Naz, A., Khan, M., Khan, W. K. Q., \& Ahmad, S. (2013). The Impact of Capital Structure and Financial Performance on Stock Returns "A Case of Pakistan Textile Industry". Middle-East Journal of Scientific Research, 16(2), 289-295.

Khanqah, V. T., Khosroshahi, M. A., \& Ghanavati, E. (2012). An Empirical Investigation of the Impact of Intellectual Capital on Firms' Market Value and Financial Performance: Evidence From Iranian Companies. International Journal of Management Business Research, 2(1), 1-12.

Lemma, T. T., \& Negash, M. (2013). Institutional, Macroeconomic and Firm-Specific Determinants of Capital 
Structure: The African Evidence. Management Research Review, 36(11), 1081-1122. https://doi.org/10.1108/MRR-09-2012-0201

Maditinos, D., Chatzoudes, D., Tsairidis, C., \& Theriou, G. (2011). The Impact of Intellectual Capital on Firms' Market Value and Financial Performance. Journal of Intellectual Capital, 12(1), 132-151. https://doi.org/10.1108/14691931111097944

Myers, S. C., \& Majluf, N. S. (1984). Corporate Financing and Investment Decisions When Firms have Information that Investors do not have. Journal of Financial Economics, 13(2), 187-221. https://doi.org/10.1016/0304-405X(84)90023-0

Ozturk, H., \& Yilmaz, A. A. (2015). Leverage and Stock Returns: Evidence from Istanbul Stock Exchange. Accounting and Finance Research, 4(4), 140-146. https://doi.org/10.5430/afr.v4n4p140

Priya, K., Nimalathasan, B., \& Piratheepan, T. (2015). Impact of Capital Structure on the Firm Value: Case Study of Listed Manufacturing Companies in Sri Lanka. Scholars World, 3(1), 47-53.

Quang, D. X., \& Xin, W. Z. (2014). The Impact of Ownership Structure and Capital Structure on Financial Performance of Vietnamese Firms. International Business Research, 7(2), 64-71. https://doi.org/10.5539/ibr.v7n2p64

Ramjee, A., \& Gwatidzo, T. (2012). Dynamics in Capital Structure Determinants in South Africa. Meditari Accountancy Research, 20(1), 52-67. https://doi.org/10.1108/10222521211234228

Ross, S. A. (1977). The Determination of Financial Structure: The Incentive-Signalling Approach. The Bell Journal of Economics, 8(1), 23-40. https://doi.org/10.2307/3003485

Salim, M., \& Yadav, R. (2012). Capital Structure and Firm Performance: Evidence from Malaysian Listed Companies. Procedia - Social and Behavioral Sciences, 65(ICIBSoS), 156-166. https://doi.org/10.1016/j.sbspro.2012.11.105

Shah, S. Z. A., \& Kausar, J. (2012). Determinants of Capital Structure of Leasing Companies in Pakistan. Applied Financial Economics, 22, 37-41. https://doi.org/10.1080/09603107.2012.678978

Sucuahi, W., \& Cambarihan, J. M. (2016). Influence of Profitability to the Firm Value of Diversified Companies in the Philippines. Accounting and Finance Research, 5(2), 149-153. https://doi.org/10.5430/afr.v5n2p149

Taghavi, M., Valahzaghard, M. K., \& Alishahi, M. (2013). Co-determination of Capital Structure and Stock Returns in Banking Industry using Structural Equation Modeling. Management Science Letters, 3(1), 2367-2372. https://doi.org/10.5267/j.msl.2013.07.001

Thi, H. N., \& Jay, H. R. (2016). Determinants of Capital Structure of the Listed Companies on Vietnam Stock Market. The International Journal of Business \& Management, 4(6), 27-35.

Titman, S., \& Wessels, R. (1988). The Determinants of Capital Structure Choice. The Journal of Finance, 43(1), 1-19. https://doi.org/10.1111/j.1540-6261.1988.tb02585.x

Tse, C. B., \& Rodgers, T. (2014). The Capital Structure of Chinese Listed Firms: Is Manufacturing Industry Special? Managerial Finance, 40(5), 469-486. https://doi.org/10.1108/MF-08-2013-0211

Ulum, I. (2017). Intellectual Capital Model Pengukuran, Framework Pengungkapan dan Kinerja Organisasi (3rd ed.). Indonesia. Universitas Muhammadiyah Malang Press.

Yang, C., Lee, C., Gu, Y., \& Lee, Y. (2010). Co-Determination of Capital Structure and Stock Returns-A LISREL ApproachAn Empirical Test of Taiwan Stock Markets. The Quarterly Review of Economics and Finance, 50(2), 222-233. https://doi.org/10.1016/j.qref.2009.12.001

Zehri, C., Abdelbaki, A., \& Bouabdellah, N. (2012). How Intellectual Capital Affects a Firm's Performance. Australian Journal of Business and Management Research, 2(8), 24-31. https://www.theglobaleconomy.com/

\section{Copyrights}

Copyright for this article is retained by the author(s), with first publication rights granted to the journal.

This is an open-access article distributed under the terms and conditions of the Creative Commons Attribution license (http://creativecommons.org/licenses/by/4.0/). 